\title{
Monetary Policy Transmission via Financing Channel for Islamic Banks in Malaysia
}

\author{
Muhammad Md Husin ${ }^{1}$ \\ Phd Candidate, Islamic Banking and Finance Institute, International Islamic University Malaysia, Kuala Lumpur, Malaysia
}

\begin{abstract}
Purpose - This paper sought to identify monetary policy transmission via financing channel in the light of systemically more important Islamic financial system in Malaysia. Focus will be centred on whether the financing channel of Islamic banks response appropriately towards monetary policy stance of Bank Negara Malaysia (BNM) which is essential in meeting the objective of the monetary policy implementation.

Design/methodology/approach - The study employs the Autoregressive- Distributed Lag (ARDL) techniques to measure the relationships between variables associated with financing, base financing rate (BFR), overnight policy rate (OPR), bond yield, exchange rate, economic output as well as inflation.

Findings - The outcome of the ARDL estimates indicate that the monetary policy transmission via financing channel is observed on short-run model. However none of the variables are statistically significant based on long-run model.

Practical implications - Result of this study could justify new approach and strategy for monetary policy formulation and implementation in Malaysia.

Originality/value - There were already a number of studies being conducted to measure the monetary policy transmission for Islamic banks in Malaysia and these studies in general proved that Islamic banks are the important conduit for channeling the monetary policy impacts. This study takes into account the recent development concerning Islamic banks and thus seeks to measure how more systematically important Islamic banks could post a threat to the overall efficiency of monetary policy transmission. The data used also reflect recent figures (January 2009 until December 2018).
\end{abstract}

Keywords: Monetary policy transmission, Islamic banks, ARDL, financing channel, pass through impact.

\section{Introduction}

Monetary policy and its implementation by central banks in general are intended to influence the state of economy. In Malaysia, monetary policy is implemented with preserving price stability and ensuring sustainable economic growth as the main objective (BNM, 2017). To achieve such objective, Bank Negara Malaysia (BNM) use the Overnight Policy Rate (OPR) as the indicator of monetary policy stance (BNM, 2004). With OPR as the primary reference rate, prices of financial instruments across the yield curve are directly influenced by the movement of OPR. In this instance, interest rate for deposit for example will increase whenever OPR is increased, effectively making it more attractive for depositor to deposit their money in the bank. Meanwhile, interest rate for loans will increase as well, hence making it more difficult for people to borrow.

The deposit and loans situation described above are example of the channels for monetary policy transmission. These channels are available both through conventional and Islamic banks. In Malaysia, Shariah compliant monetary policy rate does not exist yet and as a matter of fact, Islamic banks in Malaysia are largely guided and influenced by OPR in determining their cost of funds and subsequent profit rate charged/ offered to customers/ investors. Although OPR is fundamentally an interest-based policy rate and theoretically, it may not sound right for Islamic banks to be influenced by the OPR, given the inexistence of Shariah compliant monetary policy rate and relatively small size of market capitalisation, it has always been the case thus far. For now, such approach has proven to be efficient from the monetary policy pass-through point of view with empirical studies suggesting that pass-through impact remaining high and sizable from the OPR to Islamic money market rates (Ooi, 2008). Sukmana and Kassim (2010), Kassim and Majid (2009) and Majid and Hasin (2014) also support the idea that there is a strong link between Islamic banks and monetary policy, with Islamic banks functioning as conduit to channel the monetary policy impacts to the real economy. Notwithstanding that, the last decade saw rapid growth for Islamic banks, making them more systematically important than ever.

\footnotetext{
${ }^{1}$ The author is a Treasurer in Deutsche Bank (Malaysia) Berhad and Ph.D candidate in International Islamic University Malaysia. The views expressed in this paper are solely the author's personal views and do not represent those of the Deutsche Bank (Malaysia) Berhad and International Islamic University Malaysia.
} 
This paper thus seeks to examine the state of monetary policy transmission through the financing channel for Islamic banks in Malaysia. Due to potential arbitrage opportunity in the Malaysia's dual banking system model, the pass-through impact of interest rate to the channels for monetary policy transmission, including financing in this instance is expected to remain high and sizable. Nonetheless, as Islamic banks in Malaysia become more systematically important than ever, the magnitude and pace of the transmission process could possibly be affected to a certain extend. To ascertain this, this study uses the Autoregressive-Distributed Lag (ARDL) techniques to measure the relationships between variables associated with financing, base financing rate (BFR), overnight policy rate (OPR), bond yield, economic output as well as inflation.

This paper is divided into six parts. Following this introduction, section two presents the current state of development of Islamic banks as well as the general understanding of monetary policy transmission mechanism in Malaysia. Section three reviews briefly the previous studies on the monetary policy transmission mechanism. Section four meanwhile proceeds with the methodology and data used to carry out the transmission mechanism analysis. Section five examines the empirical findings and section six concludes the paper.

\section{THE CURRENT STATE OF DEVELOPMENT AND MONETARY POLICY TRANSMISSION FOR ISLAMIC BANKS IN MALAYSIA}

\subsection{Development of global Islamic finance}

Islamic finance offers an alternative form of financial intermediation that provides a range of high-quality financial products and services. Since last decades, it has grown to be an established and a comprehensive financial system (as depicted in Figure 1) and proves to be largely unscathed even under the challenging environment presented by the recent international financial crisis. The role of Islamic finance in the history of modern finance is widely recognised. The International Monetary Fund (IMF) for example, endorsed in May 2018 a proposal on the use of the Core Principles for Islamic Finance Regulation (CPIFR), which were developed by the Islamic Financial Services Board (IFSB) with the participation of the Secretariat of the Basel Committee on Banking Supervision. The CPIFR are intended to provide a set of core principles for the regulation and supervision of the Islamic banking industry and are designed to take into consideration the specificities of Islamic banks ${ }^{2}$.

In the early days, development of Islamic finance is concentrated just in a few countries, namely Malaysia, Iran, Saudi Arabia and the UAE but recently, the industry has grown exponentially in the international arena with positive trend and creation of growth observed from other countries as well. The Islamic Finance Development Report $2018^{3}$ shows that the global Islamic finance industry grew year-onyear by of $11 \%$ to US\$ 2.4 trillion in assets in 2017 or by CAGR growth of 6\% from 2012 (as per Figure 2). Taking into consideration the performance of each sector of the Islamic finance industry and the development of its surrounding ecosystem, the report sees potential for the industry to grow to US\$ 3.8 trillion in assets by 2023 - an average projected growth of $10 \%$ per year. The report are based on figures reported by 56 countries, mostly in the Middle East and South and Southeast Asia. Iran, Saudi Arabia and Malaysia remain the largest Islamic finance markets in terms of assets, while Cyprus, Nigeria and Australia saw the most rapid growth.

Figure 1: Islamic Finance Ecosystem in 2017

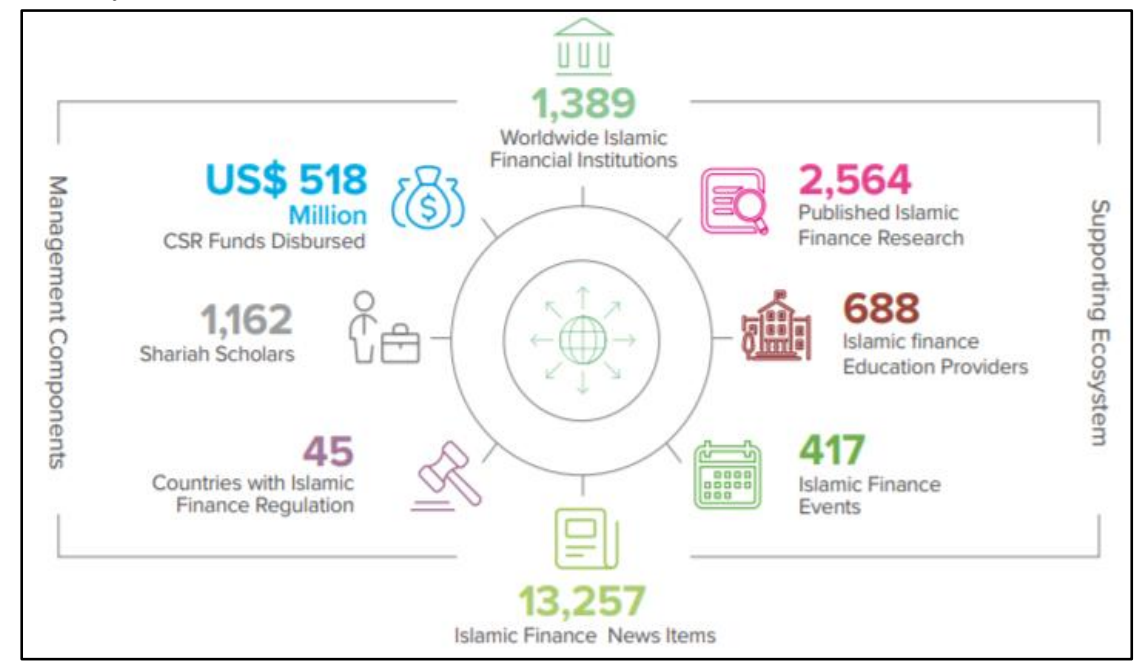

Adapted from: Islamic Finance Development Report 2018

\footnotetext{
${ }^{2}$ As highlighted in the IMF Staff Paper entitled "The Core Principles

for Islamic Finance Regulations and Assessment Methodology

${ }^{3}$ Produced by Thomson Reuters
} 
Figure 2: Global Islamic Finance Assets Growth

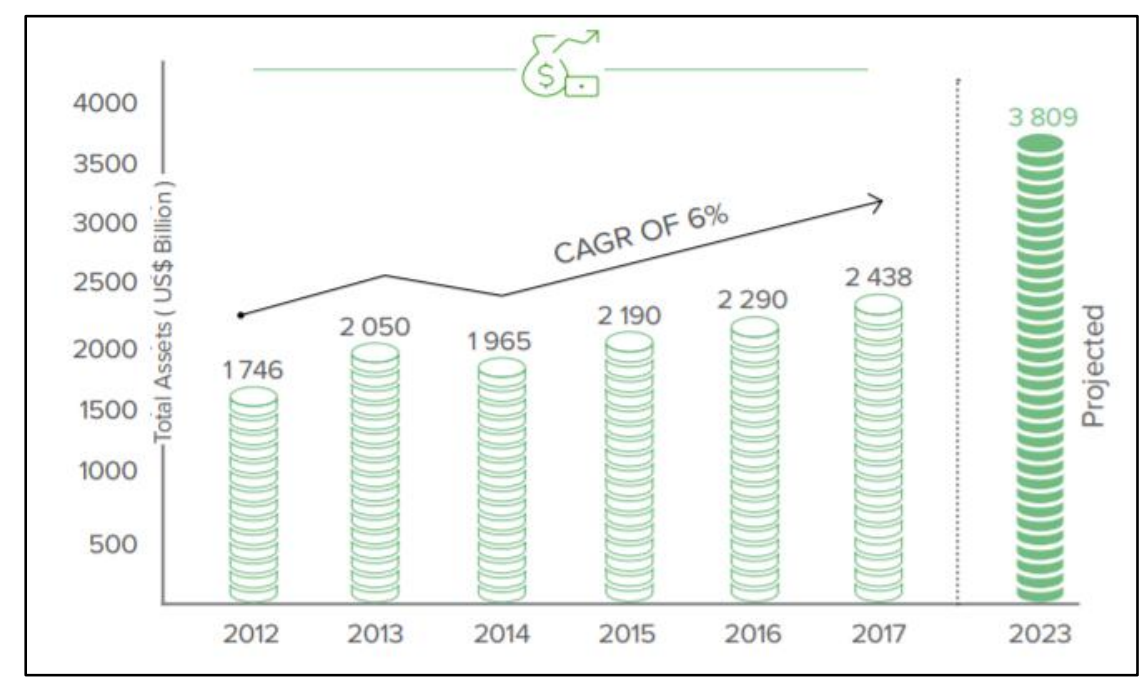

Adapted from: Islamic Finance Development Report 2018

Similar to its conventional counterparts, digitalization has emerged as a major trend that affect the Islamic finance industry. Specifically for Islamic banking sector, the digitalization is beginning to transform the sector, as seen by the launches of several digital-only Islamic banks. By promoting digitalization, Islamic banks are expected to optimize resources and reduce timeline required to complete banking transactions. Security aspect is also improved, and customers need not store cash anymore. All of these eventually point out to a better customer service experience and thus builds customer loyalty. Notwithstanding that, from monetary policy transmission point of view, the advancement in technology and digitalization warrant profound understanding as it may impact the efficiency and the objective of monetary policy implementation.

\subsection{Development of Islamic Banks in Malaysia}

In Malaysia, a comprehensive Islamic financial system which operates in parallel with the conventional financial system started way back in 1963 when the Pilgrims Management and Fund Board (better known as Tabung Haji) was established by the government to provide a systematic approach of funds mobilisation to assist people who wants to perform pilgrimage in Makkah. Since then, the Islamic financial system in Malaysia has developed from infancy to maturity stage in just a couple of decades.

This exemplifies acceptance and appreciation towards Islamic finance industry in particular Islamic banking sector as an essential form of financial intermediation that provides a range of high quality financial products and services. Islamic banking system plays an anchor role within the Islamic finance eco-system. The strategy applied in developing the system is by gradually or progressively educating and creating awareness regarding Islamic banking to mass public. One of the most imperative steps is the establishment of Bank Islam in 1983. 10 years after that in
1993, the introduction of Bank Muamalat as the second Islamic bank in the

country was announced. Subsequently, conventional banks were allowed to set-up an Islamic window within their organisation. Between the periods of 1983 to 2000, the Islamic banking industry flourished with offerings of products and services that match the offerings by its conventional counterparts. In 2001, BNM announced the granting of Islamic banking licenses to foreign Islamic banks namely Kuwait Finance House, Al Rajhi Bank and Asian Finance Bank. Since then, the landscape has changed with Islamic banks gradually offer equity based products and services.

Islamic banks also started to venture directly into property market and other asset classes, undertaking the partnership role as opposed to the traditional financier role.

In August 2006, the Malaysia International Islamic Financial Centre (MIFC) initiative was launched to promote Malaysia as a major hub for international Islamic finance.

Under the MIFC initiative, domestic and international financial institutions are welcomed to use Malaysia as a platform for their Islamic finance activities, leveraging on the comprehensive system and conducive environment for Islamic finance business available in Malaysia. Various incentives are accessible to financial institutions participating in MIFC including new licenses for conducting foreign currency businesses, attractive tax incentives and facilitative immigration policies. In 2009, the importance of Islamic banking system in Malaysia has been further enshrined in the Central Banking Act 2009, with recognition to the dual banking model thereby giving significance and due prominence to Islamic banking system.

Figure 2 below briefly described the evolution of Islamic finance in the country and how Islamic finance players have gradually became systemically more important in the context of Malaysian financial system. 
Figure 2: Structure of Malaysian Financial System

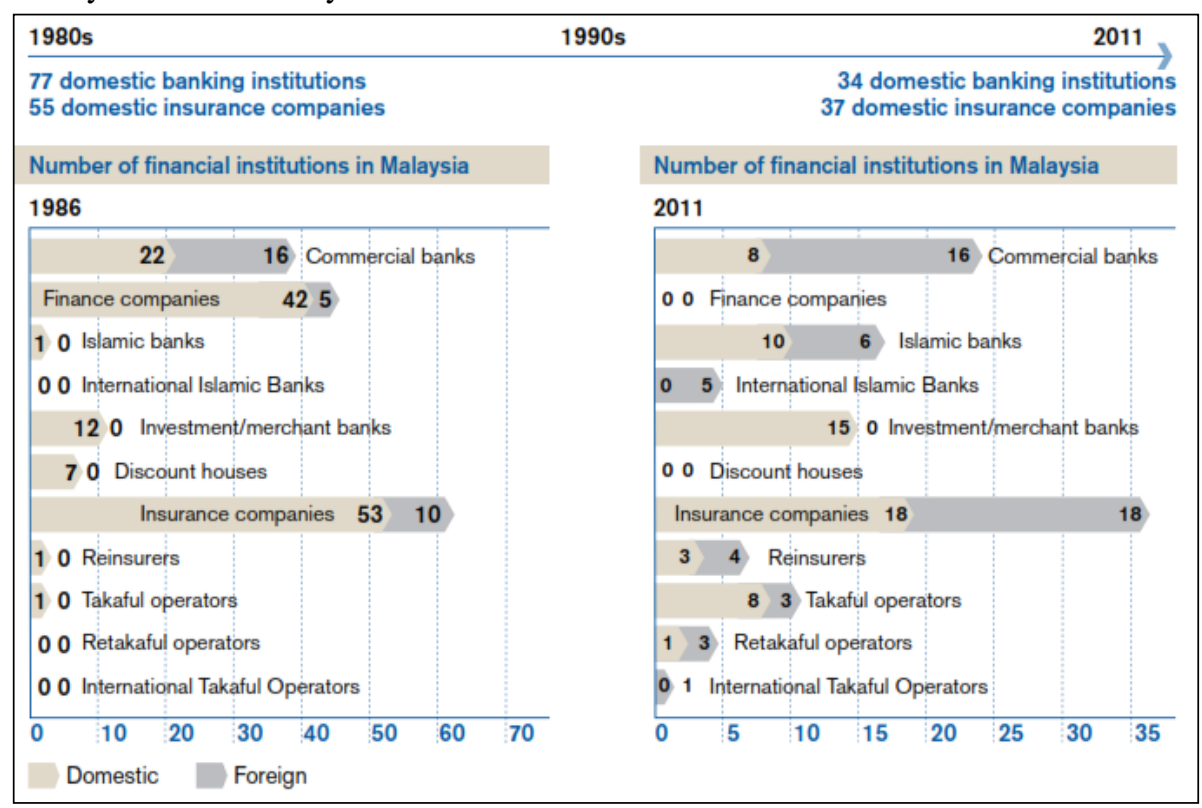

Source: BNM Financial Sector Blueprint 2011 - 2020

Within the context of growing the depth and breadth of Islamic banking system, it is imperative to also ensure that the system delivers a positive impact towards environment, economy and community. This is made possible via the implementation of Value-Based Intermediation (VBI) initiatives, which reinforces the intent of Shariah to promote good and prevent harm (BNM, 2018). VBI is defined as an intermediation function that aims to deliver the intended outcomes of Shariah through practices, conduct and offerings that generate positive and sustainable impact to the economy, community and environment, consistent with the shareholders' sustainable returns and long-term interests (BNM, 2018). Effective implementation of VBI would require solid understanding and appreciation of Shariah propositions as well as for an Islamic bank to be financially sustainable and resilient so that it has the long-term capacity and capability to continuously drive VBI agenda. Meanwhile in terms of financing growth, the outstanding amount of financing for Islamic banks in Malaysia stood at RM540.3 billion as of December 2018 (see Figure 3), with average growth of $16.7 \%$ recorded over the last 10 years. It is envisioned that by 2020 , the Islamic financing would account for $40 \%$ of total financing in 2020 (exemplified in Figure 4), underpinned by greater reach and product innovation (BNM, 2011).

Figure 3: Total Financing for Islamic Banks as of December 2018

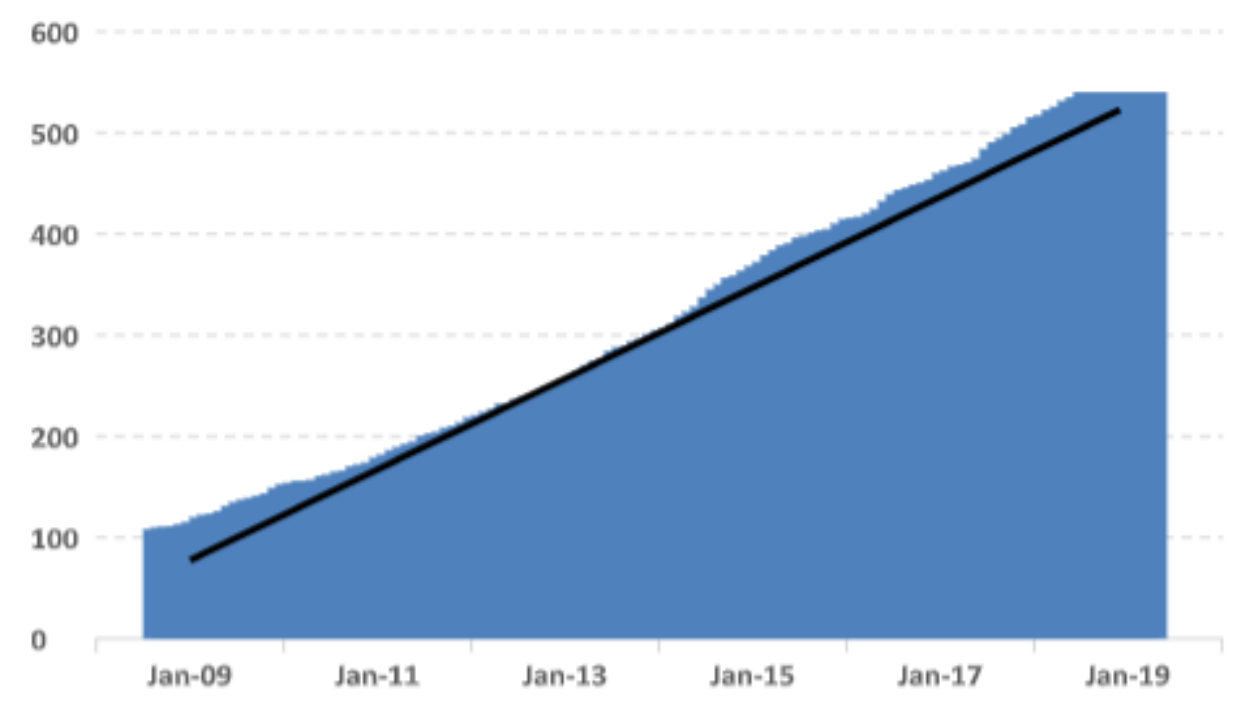

Source: BNM Monthly Highlights and Statistics 
Figure 4: Forecasted Islamic Financing by 2020

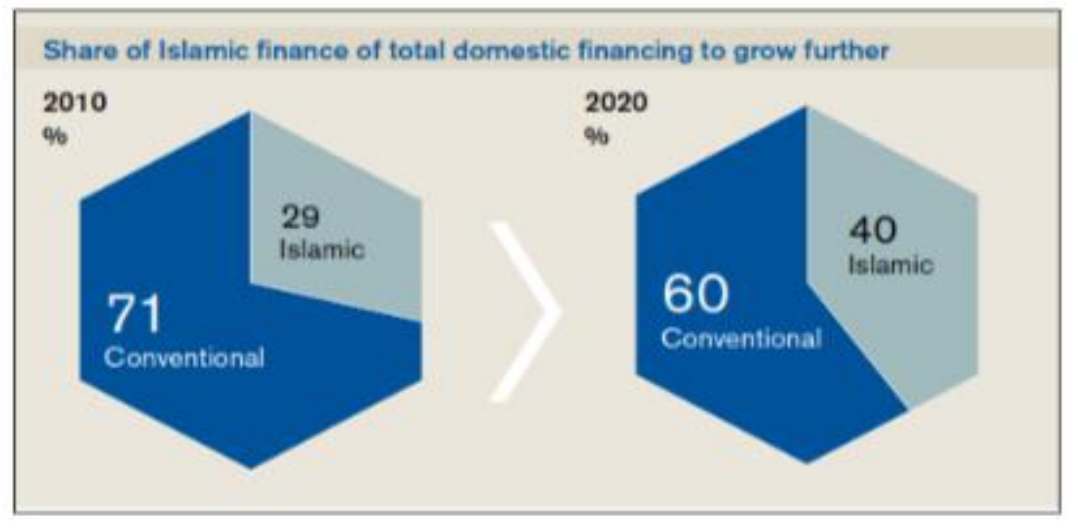

Source: BNM Financial Sector Blueprint 2011-2020

Relative to total loans or financing in the Malaysian banking system, the market share for Islamic financing as of December 2018 stood at 32.3\% (December 2009:17.2\%). This is mainly underpinned by the growth in household financing, which account for around $60 \%$ of the total Islamic financing (RAM, 2019). The growth in Islamic financing is also driven by the "Islamic First" agenda by some banking group, which give priority to the Islamic financing as opposed to conventional loans (RAM, 2019). Given such influence, which effectively means that Islamic banks have become more systemically important than ever, the efficiency of monetary policy transmission mechanism via Islamic banks and in particular via financing channel, warrant deeper understanding. This is aligned to the findings by (Ooi, 2008), which concluded that the changes in the economic structure and financial system including the emergence of an increasingly influential Islamic financial system in Malaysia, have had an important influence in shaping the increasing complexity of the relationship between monetary policy and the real economy.

\subsection{The Channels for Monetary Policy Transmission via Islamic Banks in Malaysia}

Conventionally, the monetary policy transmission mechanism is a process through which monetary policy decisions are transmitted into changes in income and inflation (Taylor, 1995). Changes in monetary policy rate thus transforms the way customers obtain financing and park their savings from and into banks. Changes in monetary policy also alter the spread of banks' financial products, which in turn may lead to different sectors of the economy being impacted, eventually affecting income and inflation. However, before the changes in income and inflation take place, the transmission process will flow within certain channels in the economy. The main two channels that are often mentioned in the literature are the "money channel" (also known as interest/ profit rate channel) and "credit channel" (Kassim and Majid, 2009). In Malaysia, the relevant channels for monetary policy transmission are briefly describes below:

Figure 4: Monetary Policy Transmission Mechanism in Malaysia

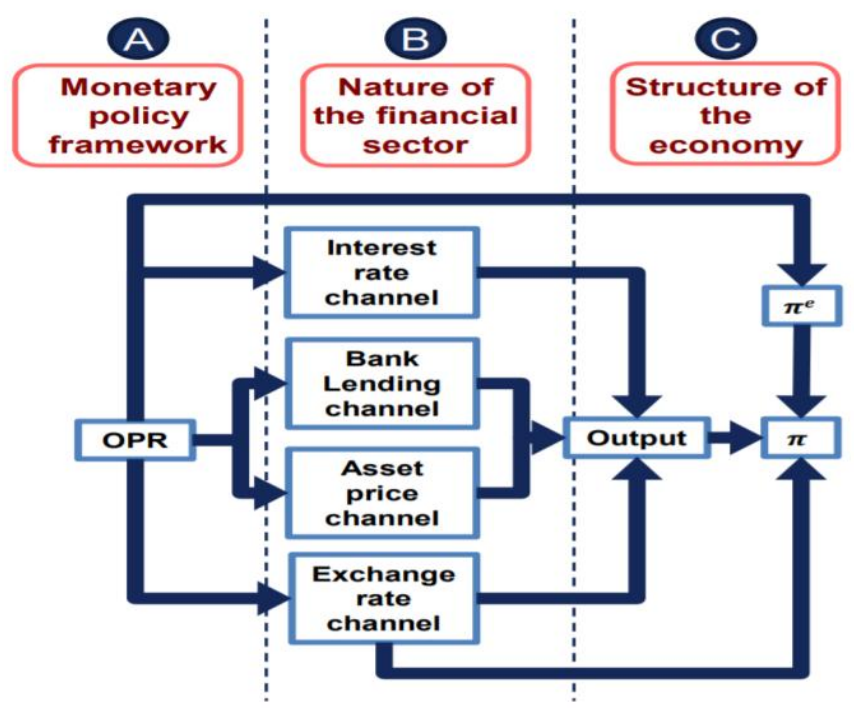

Source: BNM's presentation in BIS-CAFRAL 9th Annual Workshop of the Asian Research Networks, 21-22 March 2016, Mumbai, India 
Taking into account the nature of the dual banking system in Malaysia, the respective channels indicated in the above figure would be available via both conventional and Islamic banks. One important observation is under the practice of dual banking system; Islamic banks in Malaysia are largely guided and influenced by BNM's OPR for their pricing benchmark. OPR being an interest rate instrument theoretically may not be appropriate to be used for Islamic banks. However this is allowable from Shariah point of view given that it is merely used as a pricing indicator. This also make sense practically as currently the underlying structure for Islamic banking transactions especially on the financing side are mostly based and driven by Shariah contracts with similar risk and rewards to those of interest rate 4 .

Hence, in most cases, Islamic financial instruments are identical to the conventional instruments particularly with respect to profit rate for the financing.

Notwithstanding that, the implication is, though Islamic banks are supposed to operate on interest free principles, the economic environment in a dual banking system exposes them to the problems of conventional banks; particularly the interest rate risk (Bacha, 2004). Study by Kadir and Leong (2009) also share similar conclusion that the uses of interestbased system as benchmark expose Islamic bank financing in the dual system to interest rate risks despite operating on interest free principles. In another paper, Bacha (2008) also commented that given such relationship of the two markets, the central bank's actions in the Islamic market must reflect its actions in the conventional market. Failing which, profitable arbitrage against the central bank or a carry trade between the markets would both be feasible. Hence, no matter how supportive a central bank is of the Islamic financial sector, it cannot possibly maintain dual rates or cause changes in one market and not in the other.

\section{LITERATURE REVIEW}

\subsection{The Evolution on the Thinking of Monetary Policy}

Bindseil (2004) gave a broad overview of the evolution of academic thinking on monetary policy where he revealed that the overall strategy of monetary policy changed fundamentally in the course of the twentieth century. This implies that given relevant factors, the changes of overall strategy for monetary policy is inevitable.

Boivin, Kiley, and Mishkin (2010) also seconded such view. In their paper they argued that there have been large changes in the regulatory structure in the United States and other countries post financial crisis, and these changes have hadimportant implications for the transmission of monetary policy actions to residential investment. In Malaysia, Ooi (2008) claimed that given the growing importance of theIslamic financial system, the implications for monetary policy deserved careful study.

${ }^{4}$ Based on BNM Monthly Statistical and Highlights, 54.1\% of Islamic financing is structured using Bai Bithaman Ajil and Murabahah concept, as of December 2018

1983

\subsection{The General Understanding on Channels for Monetary Policy Transmission}

There were some detailed descriptive studies on the monetary policy transmission mechanism. These studies in general identified various channels of monetary transmission and measured how effectively changes in policy rate were transmitted to the real economy. Mishkin (1996) provided an overview of the transmission mechanisms of monetary policy, starting with interest rate channels, and going on to channels operating through other asset prices. Bernanke and Gertler (1995) meanwhile described in great details a broader credit channel, the balance sheet channel, where financial market imperfections also play a key role. Using VAR, the result of their study supports the existence of credit channel as one of the important channels for monetary policy transmission. More recently, studies by Ascarya (2014) and Bank of England (1999) discussed beyond the conventional channels for monetary transmission mechanism when both central banks included discussion about the existence of expectation channel. As acknowledged by these studies, the expectation channel influences the formation of expected inflation, which in turn affecting the behaviour of economic agents. Overall, all channels mentioned by these empirical studies are relevant and important from monetary policy transmission's perspective. Changes from policy rate also were proven to be transmitted into various sectors in the economy via these channels.

\subsection{The Monetary Policy Transmission in Malaysia}

Evidence from literature suggest that there were several attempts to look at monetary policy transmission process in Malaysia. In general, these studies look at various transmission channels without specific emphasize to the role of Islamic banks or Islamic financial instruments. One of it was Tang (2006), who examined the relative strength of the different channels of monetary policy transmission. The concerned channels are exchange rate, asset price, interest rate and credit. The result of his study shows that the interest channel is the most important in influencing output and inflation within two years' time span. Ghazali and Rahman (2005) argued that credit channel is more important than money or interest rate channel. Thus, understanding the credit market and the behaviour of banking firms in achieving their decisions is critical in the analysis of the transmission mechanism of monetary policy. Other than that Goh, Chong and Yong (2007) adopted slightly different approach, by focusing on individual channel. They investigated the bank lending channel using the ARDL model and concluded that the bank lending channel may not be effective in Malaysia as banks are able to cushion a fall in deposits through adjustments in liquid financial instruments. Meanwhile study by Tai, Sek and Har (2012) was focused on interest rate channel and indicates that post Asian Financial Crisis in 1997, the pass-through from a policy shock to lending and deposit rates in 
Malaysia has increased significantly. Interestingly when identifying key determinants of fast transmission in Malaysia, the study quoted the emerging of Islamic financial system as one of the factors, but no elaboration is made on this point. In recent period, paper by Khaw and Sivabalan (2016) look at whether the transmission of monetary policy to growth and inflation has strengthened or weakened over the past decade and what are the factors that have driven these changes. Methodology wise, the study adopted identical methodology to Tang (2006) with extended sample period.

\subsection{The Monetary Policy Transmission Through Islamic Banks}

For study that give emphasize to the role of Islamic banks in the overall monetary transmission process, observation by Sukmana and Kassim (2010) is one of the primary references. This study was an initial attempt to determine monetary policy transmission via Malaysian Islamic banking system, looking at variables representing both real economy and monetary policy. The variables are Industrial Production Index (IPI), Islamic financing (IF), Islamic deposit (ID), and overnight interest rate (ONIGHT). The result from the study suggested that the Islamic banks play an important role in the transmission process of monetary policy in Malaysia. The result of Impulse Response Functions (IRF) for example indicated that Islamic financing is positively correlated to a shock in Islamic deposits. In the context of the monetary transmission mechanism, this essentially means when BNM increases the OPR,
Islamic deposit contracted, and this would result in a contraction in Islamic financing as well as the funds use for financing are mainly source from deposit. Overall, it led to the same impact on real output, as being shown by the significant negative response of IPI to Islamic financing. Majid and Hasin (2014) meanwhile examined the importance of Islamic banks in the monetary transmission mechanism in Malaysia. The study concluded that in designing monetary policy, the central bank should consider Islamic financing as an alternative channel for monetary transmission since this channel is just as active as conventional lending channel.

This conclusion however is arguably not reflecting the existing practice of monetary transmission. Under existing dual banking practice, as proven by Ooi (2008) the monetary policy shock in Malaysia is already distributed/ channeled via conventional and Islamic banks amidst at different pace. This is also supported by the work of Sukmana and Kassim (2010) which concluded that both Islamic deposit and financing in Malaysia are statistically significant in linking the monetary policy indicator to the real output. Hence even via Islamic banks, the monetary policy shocks were already transmitted to the real economy and in this case Islamic financing is already recognised by BNM as one of the main channels for monetary transmission.

\section{DATA AND EMPIRICAL FRAMEWORK 4.1 Data}

To examine the monetary policy transmission via financing channel for Islamic banks in Malaysia, the following variables are used:

Figure 5: Data and Data Sources

\begin{tabular}{|c|c|c|}
\hline \multicolumn{2}{|c|}{ List of Variables } & Source \\
\hline FIN $^{5}$ & Outstanding amount of Islamic banks' total deposit & \multirow{7}{*}{$\begin{array}{l}\text { Various issues of BNM Monthly } \\
\text { Highlights and Statistics (previously } \\
\text { known as BNM Monthly Statistical } \\
\text { Bulletin (monthly data from January } \\
2009 \text { to December 2018) }\end{array}$} \\
\hline OPR & Overnight Policy Rate & \\
\hline BFR & Base Financing Rate & \\
\hline INF & $\begin{array}{l}\text { Consumer Price Inflation, represented by the year on } \\
\text { year changes on Consumer Price Index }\end{array}$ & \\
\hline PROD & $\begin{array}{l}\text { Industrial Production as proxy for growth, represented } \\
\text { by the year on year changes on Industrial Production } \\
\text { Index }\end{array}$ & \\
\hline ER & USDMYR Exchange Rate & \\
\hline MGS & $\begin{array}{l}\text { Indicative yield for the } 10 \text {-year Malaysian Government } \\
\text { Security }\end{array}$ & \\
\hline
\end{tabular}

As monetary policy transmission in Malaysia is targeted at influencing the price stability, a model will be developed consisting output, price stability indicator, monetary policy indicator as well as the respective channels for monetary policy transmission. Islamic banks' total financing or FIN in this instance will be the dependent variable while Overnight Policy Rate (OPR), 10-year Malaysian Government Security (MGS), Consumer Price Inflation (INF), Industrial
Production (PROD), Base Financing Rate (BFR) and Exchange Rate (ER) are the independent variables. OPR is selected as it represents the monetary policy stance of BNM. ER, MGS, BFR and FIN are channels for monetary policy transmission while INF and PROD are variables representing the objective of monetary policy implementation.

${ }^{5}$ Data for financing is transformed into natural logarithm 
In 13 terms of data frequency, the study employs monthly data from January 2009 until December 2018. All data are sourced from BNM Monthly Highlights and Statistics section available in the BNM's official website.

\subsection{Methodology}

This study uses the ARDL bounds testing procedure, coupled with relevant diagnostic analysis to examine the transmission mechanism over time and determine the specification of the model used for the analysis. Preestimation test ${ }^{6}$ such as Descriptive Statistic, Correlation Analysis and Outlier Detecting are also carried out to ensure suitability of data. The complete steps for the ARDL testing are exemplified as follows:

Figure 6: Steps for ARDL Analysis

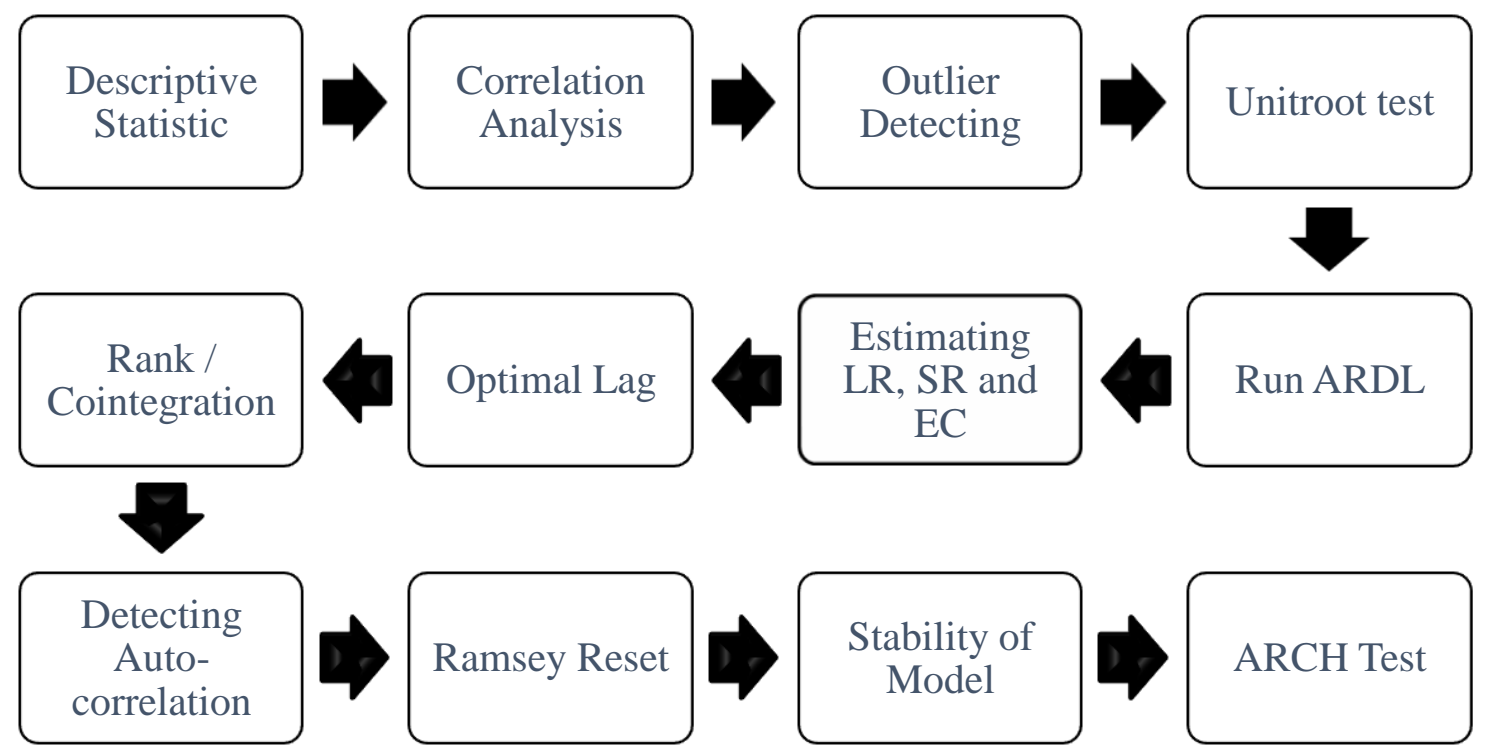

The ARDL technique is generally chosen for two reasons. Firstly, the bounds diagnosing process does not need the pretesting of the variables involved in the model for unitroots and it can differentiate the dependent and independent variables and permit the approach to check for the existence of relationship among variables in level regardless of whether the original regressors are $1(0), 1(1)$ or mutually cointegrated. Secondly, the method is relatively more effective in finite or small sample data size as is the case in this research. Moreover, it can evaluate the short- run and long-run relationships in monetary policy model simultaneously.

ARDL approach has three main stages. The first stage is to check the existence of cointegration between variables in the equation system. In confirming the cointegration as established by Pesaran et al. (2001), in the first stage, it is necessary to identify the long-run equation as a VAR equation of order $\mathrm{p}$, to check for the existence of a long-run or a level relationship between variables. The primary purposes of running an ARDL model is to use it as the basis for doing the bounds test. This will be done by running a Ftest for the joint significance of coefficients of lagged levels of variables. The null and alternative hypotheses would be:

(No long run relationship / co-integration)

(There is a long run relationship / co-integration)
Hence, if the F-statistic is higher than the upper critical value, the null hypothesis says that there is no long-run relationship will be rejected irrespective of the orders of variables. Otherwise, if the F-statistic drop below the lower critical value, the null hypothesis cannot be rejected, and it implies that there is no long-run relationship between series. Finally, if the F-statistic has a value between lower and upper critical level, the finding is inconclusive. As the existence of cointegration (long run relationship) is confirmed, the research continues to the second stage which is to perform the long-run model. Conclusively, the next step in the ARDL model is about assessing an Error Correction Model (ECM) to reach the short-run dynamics of model. This ECM delivers the means of integration the short-run performance of variable with its long-run performance.

In terms of model construction, given that transmission of monetary policy involves several stages which specifies propagation of monetary policy shocks from financial system to the real economy, the following equation is developed and generally used for the analysis:

\footnotetext{
${ }^{6}$ Outcome from pre-estimation test indicates that data are suitable for the study
} 
(1)

Where:

LnFINt $=$ Natural Log of Outstanding amount of Islamic bank's financing at time $t$

BFRt $=$ Base Financing Rate at time $t$

$\mathrm{OPRt}=$ Overnight policy rate $(\mathrm{OPR})$ at time $\mathrm{t}$.

MGSt $=$ Indicative yield for 10-year Malaysian government security (MGS) at time t.

$\mathrm{INFt}=$ Year on year changes for Consumer Price Index at time t.

PRODt $=$ Year on year changes for Industrial Production Index at time $t$.

$\mathrm{ERt}=\mathrm{USDMYR}$ exchange rate (ER) at time t.

e_t $=$ Residual of model over the time or error terms.

$\beta \_0=$ constant or intercept. $\beta \_\mathrm{j}=$ Coefficients of determinations.

$\mathrm{t}=$ denotes the time dimension.

\section{EMPIRICAL FINDINGS}

\subsection{Result from Unit Root Test}

Although not necessarily required for ARDL, the unit root test is still undertaken to examine the property of time series, i.e., the stationary properties. This is very critical to avoid spurious regression. In this study, we employ both Augmented Dickey-Fuller (ADF) and Philipps-Perron (PP) unit root test. The advantage of this test is that it allows for a wide class of auto correlated and mildly heterogenous series. The test was conducted in the log level and first difference, and in both cases, it uses intercept and trend and intercept.

Figure 7: Unit-Root Test

\begin{tabular}{|c|c|c|c|c|}
\hline & \multicolumn{4}{|c|}{ January 2007 to December 2018} \\
\hline & \multicolumn{4}{|c|}{$\begin{array}{c}\text { Intercept } \\
\text { (Trend and intercept) }\end{array}$} \\
\hline & \multicolumn{2}{|c|}{$\mathrm{ADF}$} & \multicolumn{2}{|c|}{ PP } \\
\hline Variables & Level & $1^{\text {st }}$ diff & Level & 1st diff \\
\hline LnFIN & $\begin{array}{c}4.9445 * * * \\
(0.3136)\end{array}$ & $\begin{array}{c}8.2866 * * * \\
(9.7171)^{* * *}\end{array}$ & $\begin{array}{c}4.7706 * * * \\
(0.3605)\end{array}$ & $\begin{array}{c}8.3652 * * * \\
(9.6581) * * *\end{array}$ \\
\hline OPR & $\begin{array}{c}1.2052 \\
(1.6216)\end{array}$ & $\begin{array}{c}7.3138 * * * \\
(7.5318) * * *\end{array}$ & $\begin{array}{c}1.3232 \\
(1.8955)\end{array}$ & $\begin{array}{c}13.1743 \text { *** } \\
(13.4115)^{* * *}\end{array}$ \\
\hline BFR & $\begin{array}{l}8.2046 * * * \\
(9.2420) * * *\end{array}$ & $\begin{array}{l}10.4612 * * * \\
(10.4150) * * *\end{array}$ & $\begin{array}{l}8.8441 * * * \\
(9.6393) * * *\end{array}$ & $\begin{array}{l}93.5737 * * * \\
(90.9533) * * *\end{array}$ \\
\hline MGS & $\begin{array}{c}4.5966 * * * \\
(4.5338) * * *\end{array}$ & $\begin{array}{c}13.6224 * * * \\
(13.5384) * * *\end{array}$ & $\begin{array}{l}5.0353 * * * \\
(4.9892) * * *\end{array}$ & $\begin{array}{c}16.4784 * * * \\
(16.4962) * * *\end{array}$ \\
\hline PROD & $\begin{array}{c}4.3823 * * * \\
(5.2976) * * *\end{array}$ & $\begin{array}{c}16.3655 * * * \\
(16.4648) * * *\end{array}$ & $\begin{array}{l}5.3111 * * * \\
(5.2976) * * *\end{array}$ & $\begin{array}{l}17.0459 * * * \\
(17.6143) * * *\end{array}$ \\
\hline INF & $\begin{array}{l}3.8892 * * * \\
(3.9657) * *\end{array}$ & $\begin{array}{c}6.8431 * * * \\
(6.8136) * * *\end{array}$ & $\begin{array}{l}3.1514 * * \\
(3.1978) *\end{array}$ & $\begin{array}{c}7.2200 * * * \\
(7.1875) * * *\end{array}$ \\
\hline ER & $\begin{array}{c}0.6754 \\
(-2.2184)\end{array}$ & $\begin{array}{l}10.1290 * * * \\
(-10.2 .96) * * *\end{array}$ & $\begin{array}{c}0.6754 \\
(-2.2546)\end{array}$ & $\begin{array}{c}10.1360 * * * \\
(-10.2379) * * *\end{array}$ \\
\hline
\end{tabular}

Note: $* * *$, and $* * *$ denotes significant at $10 \%, 5 \%$ and $1 \%$ respectively

Figure 7 displays the result of unit-root test analysis through ADF and PP methods. The ADF test results exhibit that for the full period of the study, the null hypothesis of existence of unit-root rejected at level for LnFIN, BFR, MGS, PROD and INF, hence they are stationary in level or I (0). The rest of variables (OPR and ER) are found to be stationary in first difference or I(1). The PP test produces similar results and thus reaffirmed the findings of the ADF test. In summary, these results indicate that some variables behave as random walks. In other words, historical data of these variables cannot be used to predict future trends. Secondly, given such outcome, where some variables are significant at level while some are significant at first difference, the best time-series analysis that can handle both $\mathrm{I}(0)$ and $\mathrm{I}(1)$ simultaneously is ARDL.
Confirming the data suitability by unit-root test for the ARDL analysis, we continue to examine whether long-run equilibrium exists amongst the variables by conducting the bound test.

\subsection{Result from Bound Test}

The initial step in ARDL model is to check the existence of long-run relationship between dependent variable and independent variables by using "bound testing" processes on the conditional unrestricted error correction models (UECM). The bound test principally set k (lag-length) as automatic choice (with trend and constant) for all lag orders. Then, it applies the joint significance test (F-statistic) for checking the long-run parameters. 
Figure 8: Bound Test

\begin{tabular}{|l|c|c|}
\hline \multirow{2}{*}{} & \multicolumn{2}{|c|}{ January 2007 to December 2018 } \\
\cline { 2 - 3 } & AIC & SC \\
\hline F-statistic & 67.4317 & 68.2148 \\
\hline Lag length & 6 & 6 \\
\hline Significant based on Pesaran & $* * *$ & $* * *$ \\
\hline Significant based on Narayan & $* * *$ & $* * *$ \\
\hline
\end{tabular}

Note:

- $*$, **, and $* * *$ denotes significant at $10 \%, 5 \%$ and $1 \%$ respectively

- Based on Pesaran, the upper value bounds are 3.23, 3.61 and 4.43 for 10\%, 5\% and 1\% significance level respectively

- Based on Narayan, the upper value bounds for $\mathrm{K}(6)$ are 3.75, 4.43 and 6.11 for $10 \%, 5 \%$ and $1 \%$ significance level respectively

The outcomes of bounds tests (computed F-statistics) is displayed in Figure 8. The respective critical values for the upper and lower bounds provided by Pesaran et all (2001) and Narayan (2005) are also included. The calculated Fstatistics calculated using AIC and SC approach are 67.4317 and 68.2148 respectively, greater than the upper bound critical values proposed by both Pesaran et all (2001) and Narayan (2005). This implies that the null hypothesis of no- cointegration can be rejected, and long-run relationship is observed between variables used in the study.

\subsection{Result from Cointegration Test (Long-Run Analysis)}

Based on the bound test, it is confirmed that the long-run relationship among the variables exists and therefore, the long and short-run models can be constructed. Figure 9 exemplified the long and short-run estimates based on ARDL.

Figure 9: Long and Short Run Model Estimates

\begin{tabular}{|c|c|c|}
\hline \multicolumn{3}{|c|}{ Jan 2007 to Dec 2018} \\
\hline \multicolumn{3}{|c|}{$\begin{array}{c}\text { Coefficient } \\
\text { (Std Error) }\end{array}$} \\
\hline \multirow{2}{*}{ Long-run model } & \\
\hline \multirow{2}{*}{ INF } & -0.1961 & $-0.0008^{*}$ \\
& $(0.2187)$ & $(0.0005)$ \\
\hline \multirow{2}{*}{ ER } & -0.9059 & $0.0181^{* *}$ \\
& $(1.6113)$ & $(0.0007)$ \\
\hline \multirow{2}{*}{ MGS } & 1.5388 & $-0.0070^{* * *}$ \\
& $(1.7545)$ & $(0.0030)$ \\
\hline \multirow{2}{*}{ OPR } & 0.0345 & 0.0001 \\
& $(1.0258)$ & $(0.0048)$ \\
\hline \multirow{2}{*}{ PROD } & 0.0545 & 0.0002 \\
& $(0.0601)$ & $(0.0001)$ \\
\hline \multirow{2}{*}{ ROR } & -0.0937 & -0.0004 \\
& $(0.2460)$ & $(0.0009)$ \\
\hline
\end{tabular}

Note: $* * *$, and $* * *$ denotes significant at $10 \%, 5 \%$ and $1 \%$ respectively

For the short-run model, INF, ER and MGS are found to be statistically significant in affecting Islamic financing. This means that movement in INF, ER and MGS will affect the behaviour of Islamic financing. The direction of coefficient of the variables are also mostly consistent with those of the long run, except for the ER and MGS.

However for the long-run model, none of the variables are statistically significant in affecting Islamic financing. This indicates that changes in monetary policy stance does not necessarily influence changes in the behaviour of Islamic financing. There are a couple of reasons for this and in line with Khaw and Sivabalan (2016), we believe that dynamic changes in the structure of banking system and regulatory requirements may alter the functioning of Islamic financing channel, resulting in weakened or impaired monetary policy transmission. Such factors include requirement for prudent credit assessment by banks. A lower interest rates environment theoretically should influence demand for 
financing, but the supply of financing depends on the bank's judgment of credit risk profile of the potential borrower. Based on BNM Guideline on Responsible Financing (2011), banks are expected to conduct a comprehensive check on customer's overall indebtedness by obtaining information on the customer's outstanding debt obligations. In this case, how monetary policy can affect the macro-economy (inflation and growth) depends on both the bank's judgment of credit risk profile of the borrower as well as borrower sentiment on investment (whether pricing is appropriate or not etc). More often than not, these two elements do not move in line, resulting to impaired monetary policy transmission. This substantiate another finding by Khaw and Sivabalan (2016) that in recent years, a sizeable portion of monetary policy effects occur outside the traditional interest rate and bank lending channels. In terms of direction, Islamic financing is positively correlated to OPR but at the same time has a negative relationship with BFR. This means that if the OPR increases by one percent, the Islamic financing will increase by $0.03 \%$. At the same time if BFR increases by one percent, the Islamic financing will decrease by $0.09 \%$. Meanwhile to complement the main regression analysis, several diagnostic tests are also undertaken. The outcome of the Breusch-Godfrey serial correlation test indicates no evidence of serial correlation, while the white test for heteroskedasticity also indicates no evidence of heteroskedasticity. The test for checking model specification i.e. the Ramsey Reset indicates no issues of misspecification and CUSUM and CUSUM square test shows that the plot of these statistics largely remains within the critical bounds of the $5 \%$ significance level.

\section{CONCLUSION}

This paper examines the monetary policy transmission via financing channel of Islamic banks in Malaysia. The cointegration result indicates that a short-run relationship exists among the variables that comprise proxy of monetary policy indicators and channels for monetary policy transmissions. However this is not observed under the longrun model. This is largely in line with recent study by Khaw and Sivabalan (2016). From the author point of view, it is important that the outcome of this study to be in line with those of Khaw and Sivabalan (2016) because their study is recently conducted and as BNM staff they exemplified to a certain extend actual BNM's experience in formulating monetary policy and this is important because it provide practitioner's perspective on the subject of the research.

The earlier concern by Ooi (2008) about impact of increased prominence of Islamic banks and Islamic finance in general towards the monetary policy transmission process appears to be less significant at this point. As discussed earlier, atleast on short-term basis, the outcome of statistical analysis indicates that the Islamic banks are important conduit for the overall monetary policy transmission process, similar to its conventional counterparts. The outcome of this study also may shed some light on the need for a dedicated Islamic monetary policy (IMP). From monetary policy transmission perspective, an IMP is not required because even under existing monetary policy regime, it is proven that the monetary policy stance is transmitted via Islamic banks.

\section{REFERENCES}

1. Ascarya, A. 2014. International Journal of Economics, Management and Accounting 22, No 1 (1-32). Monetary Policy Transmission Mechanism Under Dual Financial System in Indonesia: Interest-Profit Channel. Kuala Lumpur.: The International Islamic University Malaysia.

2. Ayub, M. 2007.Understanding Islamic Finance. West Sussex.: John Wiley \& Sons Ltd.

3. Bacha,O.I. 2004. Munich Personal RePEc Archive. Dual Banking Systems and Interest Rate Risk for Islamic Banks. Kuala Lumpur.: INCEIF.

4. Bacha, O.I. 2008. Munich Personal RePEc Archive. The Islamic Inter bank Money Marketand a Dual Banking System: The Malaysian Experience. Kuala Lumpur.: INCEIF

5. Bank Negara Malaysia. 2018. Annual Report 2017. Kuala Lumpur.: BNM.

6. Bank Negara Malaysia. 2011.Financial Sector Blueprint 2011 - 2020. Kuala Lumpur.: BNM.

7. Bank Negara Malaysia. 2019.Financial Stability and Payment Systems Report 2018. Kuala Lumpur.: BNM.

8. Bank of England.1999.Bank of England Quarterly Bulletin May 1999. The Transmission Mechanism of Monetary Policy. London.

9. Bernanke,B.S and Gertler. 1995. NBER Working Paper No 5146. Inside the Black Box: The Credit Channel of Monetary Policy Transmission. Massachusetts: Cambridge.

10. Bindseil, U. 2004. Monetary Policy Implementation: Theory, Past and Present. Oxford.: Oxford University Press, 2004.

11. Boivin, Kiley and Mishkin, F. S. 2010. NBER Working Paper Series. How Has The Monetary Transmission Mechanism Evolved Over Time. Massachusetts: Cambridge.

12. Cevik,S. and Charap, J. 2011. IMF Working Paper WP/11/156, 2011. The Behavior of Conventional and Islamic Bank Deposit Returns in Malaysia and Turkey. Washington: IMF.

13. Ghazali, N.A. and Rahman, A. A. 2005. International Journal of Economics and Management 13 No 1. The Transmission Mechanism of Monetary Policy in Malaysia: Through Bank Loans or Deposits?. Kuala Lumpur.: The International Islamic University Malaysia.

14. Goh, K.L. Chong, C.S. and Yong, S. L. 2007. Applied Econometrics and International 
Development Vol 7-2. Bank Lending Channel for Monetary Policy Transmission in Malaysia: An ARDL Approach. Spain.: Euro-American Association of Economic Development Studies.

15. Havranek, T. and Rusnak.2012.International Journal of Central Banking.Transmission Lags of Monetary Policy: A Meta-Analysis. Prague.

16. IMF.2018. IMF Policy Paper. The Core Principles for Islamic Finance Regulations and Assessment Methodology. Washington D.C: International Monetary Fund, 2018

17. Kassim,S. and Majid. M.S.A. 2009.International Journal of Banking and Finance: Vol. 6: Issue 2, Article 2 2009. The Role of Bank Loans and Deposits in the Monetary Transmission Mechanism in Malaysia.Sintok: Universiti Utara Malaysia.

18. Khaw, D. and Sivabalan, R. 2016.BIS-CAFRAL 9th Annual Workshop of the Asian Research Networks. Slides Presentation onThe Monetary Policy Transmission Mechanism in Malaysia: Evolution Over the Past Two Decades.

19. Khaw, D. and Sivabalan, R. 2016.The Monetary Policy Transmission Mechanism in Malaysia: Evolution Over the Past Two Decades. Kuala Lumpur.

20. Majid, M.S.A and Hasin. Z. 2014. Journal of Economic Cooperation and Development, 35, 2, 137-166. Islamic Banks and Monetary Transmission Mechanism in Malaysia. Kuala Lumpur: Emerald Group Publishing Limited.

21. Mishkin, F.S. 1996. NBER Working Paper No 5464. The Channels of Monetary Transmission: Lesson for Monetary Policy. Massachusetts: Cambridge.
22. Narayan, P. K. 2005. Applied Economics 37, pp. 1979-1990. The Saving and Investment Nexus for China: Evidence From Cointegration Tests.

23. Ooi, Sang K. 2008. The monetary transmission mechanism in Malaysia: current developments and issues. Basel: Bank for International Settlement.

24. Pesaran, Hashem, M. Shin, Y and Smith, R.J. 2001. Journal of Applied Econometrics 16(3): 289-326. Bounds Testing Approaches to the Analysis of Level Relationships. Washington: Wiley.

25. Sukmana, R. and Kassim. S.H. 2010. International Journal of Islamic and Middle Eastern Finance and Management Vol 3 No 1 2010. Roles of the Islamic banks in the monetary transmission process in Malaysia. Kuala Lumpur: Emerald Group Publishing Limited.

26. Tai, P.N. Sek, S.K. and Har, W. M. 2012. International Journal of Economics and Finance Vol 4 No 2. Interest Rate Pass-Through and Monetary Transmission in Asia. Ontario.: Canadian Center of Science and Education.

27. Tang, H.C. 2006. CAMA Working Paper Series. The Relative Importance of Monetary Policy Transmission Channels in Malaysia. Canberra: The Australian National University.

28. Taylor, J.B. 1995. Journal of Economic Perspectives-Volume 9, Number 4--Fall 1995-Pages 11-26. The Monetary Transmission Mechanism: An Empirical Framework. Washington: American Economic Association.

29. Thomson Reuters. 2018. Islamic Finance Development Report 2018. London: Thomson Reuters. 